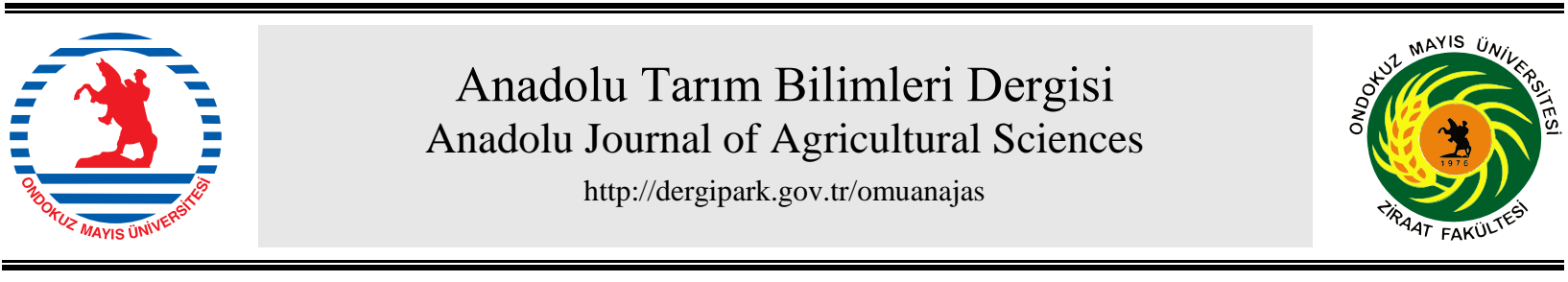

Research/Araşturma

Anadolu Tarım Bilim. Derg./Anadolu J Agr Sci, 32 (2017)

ISSN: 1308-8750 (Print) 1308-8769 (Online) doi: 10.7161/omuanajas.288864

\title{
Impacts of the support policies on agricultural efficiency and total factor productivity in Turkey
}

\author{
Nevra Alhas Eroğlua , Mehmet Bozoğlu ${ }^{b^{*}}$ \\ ${ }^{a}$ Samsun Regional Office of Turkish Statistical Institute, Samsun. \\ ${ }^{b}$ Ondokuz Mayis University, Faculty of Agriculture, Department of Agricultural Economics, 55200 Atakum, Samsun \\ *Corresponding author/sorumlu yazar: mehmetbo@omu.edu.tr
}

Received/Geliş 10/06/2016 Accepted/Kabul 06/10/2016

\begin{abstract}
Productive and efficient use of the production factors in the agricultural sector is very essential in order to meet the food demand of increasing population, to raise life standards of farmers and to realize agricultural development. The aim of this research is to explore the effects of support policies on the efficiency and the total factor productivity (TFP) of Turkish agriculture during the period of 1980 2009. Data Envelopment Analysis (DEA) and Malmquist Index were used to analyze the efficiency of resource utilization and TFP. After the period of 2000 in which the support policies mainly compatible with market mechanism, the resources were used more efficient than the previous period. Although TFP of agricultural sector in 2000's decreased by $3.6 \%$ compared to 1980 's, it increased by $27 \%$ with respect to 1990's and the increase in productivity was entirely arised from the technological change. In order to enhance the technical efficiency and TFP in the agricultural sector, it is necessary to adapt new technologies which are accompanied by improving the competition conditions in the agricultural markets.
\end{abstract}

Destekleme politikalarının Türkiye'deki tarımsal etkinlik ve toplam faktör verimliliğine etkileri

\section{ÖZET}

Tarım sektöründe üretim faktörlerinin verimli ve etkin kullanımı, artan nüfusun gıda talebinin karşılanması, çiftçilerin hayat standartlarının yükseltilmesi ve tarımsal kalkınmanın gerçekleştirilmesi için çok büyük önem taşımaktadır. Bu araştırmanın amacı, destekleme politikalarının Türkiye'nin 19802009 dönemindeki tarımsal etkinliği ve toplam faktör verimliliğine etkilerinin ortaya konulmasıdır. Destekleme politikalarının piyasayla uyumlu olduğu 2000 sonrası dönemde kaynaklar, önceki döneme göre daha etkin kullanılmıştır. Tarım sektörünün 2000'li yıllardaki toplam faktör verimliliği 1980'li yıllara göre \% 3.6 azalmasına rağmen, 1990’lı yıllara göre \% 27 artmış ve verimlilikteki artış tamamen teknolojik gelişmeden kaynaklanmıştır. Tarım sektörünün ekinliği ve verimliliğinin artırılabilmesi için tarım sektöründe yeni teknolojilere uyum sağlama ile birlikte rekabet koşullarının iyileştirilmesi gerekmektedir.

Keywords:

Agricultural support policy

Data envelopment analysis

Malmquist index

Total factor

productivity

Turkey

\section{Introduction}

As agriculture has been one of the most important sectors of economy in Turkey, it has been supported by different kind of policies. When we look at the agricultural support policies in Turkey from 1980 to 2009 , it is obvious that this 30 years period is mainly divided into two sub-periods according to the objectives and instruments of policies. According to the policy objectives of Turkey, after 2000, there was a considerable change in the objectives of agricultural policies and some concepts such as food safety, rural development, and environment were started to be taken into consideration in the policy framework. Depending on the policy objectives, main agricultural instruments of 1980-1999's were input and credit subsidies, purchases and price supports, premium and compensatory payments, tax exemption for small farmers, general service payments and import tariffs and export subsidies. When we came to 2000's, Turkish agricultural policy changed according to internal dynamics and especially external factors such as Common Agricultural Policy of European Union, agreements of World Trade Organization, Agricultural 
Reform Implementation Project (ARIP) of World Bank and stand by programs of International Money Fund on prices, privatization, financial support limitations and physical limitations on support purchases. So, after 2000, mainly within the context of ARIP, agricultural instruments have substantially been direct income support, alternative crops/farmer transition, commercialization and privatization and project support services thanks to the improvement of market mechanism.

Efficiency and productivity growth in agriculture has been a core subject of studies in recent years on account of new data sets and techniques. A considerable part of these studies analyzing cross-country differences in agricultural productivity were conducted (Kawagoe et al., 1985, Kawagoe and Hayami, 1985; Lau and Yotopoulos, 1989; Fulginiti and Perrin, 1993, 1997; Arnade, 1998; Nin et al., 2003; Trueblood and Coggins, 2003; Galanopoulos et al., 2004; Nkamleu, 2004; Coelli and Rao, 2005). Some other studies compared efficiency and productivity between Turkey and EU or transition economies (Zaim and Çakmak, 1998; Deliktas et al., 2005; Avc1 and Kaya, 2008; Cankurt et al., 2010; Tunca et al., 2014). There are also a number of studies on comparison of agricultural productivity of provinces or regions (Mao and Koo, 1997; Thirtleet al., 2003; Umetsuet al., 2003; Chen et al., 2008;). Differently from these studies, Brümmeret al. (2006) analyzed the productivity of agricultural sector by means of agricultural policies in China. Although the studies on efficiency and productivity of agriculture substantially depend on cross-country analyses, there are a few studies about the effects of the policies on efficiency and productivity. The principal aim of this study is to analyze efficiency and TFP, technology and efficiency changes in Turkish agriculture according to three periods.

\section{Data and Methods}

The index calculated by Färe et al. (1994) enable to study with quantity data without use of price in multi input and output models. At the same time, the components of technical efficiency change and technical change can be clearly identified.

Caves et al. (1982) defined Malmquist Index by the help of distance functions in respect of two different periods. That is;

$$
M^{t}=\frac{D_{0}^{t}\left(x^{t+1}, y^{t+1}\right)}{D_{0}^{t}\left(x^{t}, y^{t}\right)}
$$

In the function, technology of $t+1$ is calculated relative to a common technology, $t$, and Malmquist Index for $\mathrm{t}+1$ period is;

$$
M^{t+1}=\frac{D_{0}^{t+1}\left(x^{t+1}, y^{t+1}\right)}{D_{0}^{t+1}\left(x^{t}, y^{t}\right)}
$$

Note that, equation 3 is the geometric mean of two TFP indices.

$$
M_{0}\left(x^{t+1}, y^{t+1}, x^{t}, y^{t}\right)=\left[\left(\frac{D_{0}^{t}\left(x^{t+1}, y^{t+1}\right)}{D_{0}^{t}\left(x^{t}, y^{t}\right)}\right)\left(\frac{D_{0}^{t+1}\left(x^{t+1}, y^{t+1}\right)}{D_{0}^{t+1}\left(x^{t}, y^{t}\right)}\right)\right]^{\frac{1}{2}}
$$

An equivalent way of writing this productivity index is;

$$
M_{0}\left(x^{t+1}, y^{t+1}, x^{t}, y^{t}\right)=\frac{D_{0}^{t+1}\left(x^{t+1}, y^{t+1}\right)}{D_{0}^{t+1}\left(x^{t}, y^{t}\right)} *\left[\left(\frac{D_{0}^{t}\left(x^{t+1}, y^{t+1}\right)}{D_{0}^{t+1}\left(x^{t+1}, y^{t+1}\right)}\right)\left(\frac{D_{0}^{t}\left(x^{t}, y^{t}\right)}{D_{0}^{t+1}\left(x^{t}, y^{t}\right)}\right)\right]^{\frac{1}{2}}
$$

where the ratio outside the square brackets measures the technical efficiency change and inside measures the technical change.

Finally, value of index greater than 1 indicates positive TFP growth and less than 1 indicates TFP decline. The change in one of the components will result in TFP change. The value of technical change greater than 1 can be defined as catching up whereas the technical change greater than 1 is innovation.

\section{Results and Discussion}

Technical efficiency scores and average of decades under the assumption of constant return to scale are reported in Table 1. The results of the research are summarized according to efficiency and TFP calculations. 
Table 1. Technical efficiency scores

\begin{tabular}{cccccc}
\hline Years & $\begin{array}{c}\text { Technical } \\
\text { Efficiency }\end{array}$ & Years & $\begin{array}{c}\text { Technical } \\
\text { Efficiency }\end{array}$ & Years & $\begin{array}{c}\text { Technical } \\
\text { Efficiency }\end{array}$ \\
\hline 1980 & 1.000 & 1990 & 0.989 & 2000 & 0.987 \\
1981 & 1.000 & 1991 & 0.997 & 2001 & 0.995 \\
1982 & 1.000 & 1992 & 1.000 & 2002 & 1.000 \\
1983 & 0.987 & 1993 & 0.939 & 2003 & 1.000 \\
1984 & 1.000 & 1994 & 1.000 & 2004 & 1.000 \\
1985 & 0.988 & 1995 & 0.966 & 2005 & 1.000 \\
1986 & 0.971 & 1996 & 0.972 & 2006 & 1.000 \\
1987 & 0.922 & 1997 & 0.941 & 2007 & 0.972 \\
1988 & 1.000 & 1998 & 1.000 & 2008 & 1.000 \\
1989 & 0.932 & 1999 & 0.965 & 2009 & 1.000 \\
\hline Average & 0.979 & Average & 0.976 & Average & 0.995 \\
\hline
\end{tabular}

The period before 2000's in which substantially the intervention price was applied, the number of the technically efficient years are fewer than the period after 2000 's that has been ruled by the market mechanism. Besides the average technical efficiency is higher in the third period comparing to the first two. Note that in technically inefficient years, not only the growth rate of agricultural gross national product was negative, but also internal terms of trade was developed to the disadvantageous of agriculture. On the other hand, any of these indicators is not solely explanatory because after 2000, in some technically efficient years, internal terms of trade were under 100. In Table 2, it can be identified that the technically most efficient period is 2000-2009. This is most likely due to the fact that policy reforms of market mechanism and the instruments such as direct income support and premium payment intervention is superior to the intervention prices and input supports. Table 2 summarizes the Malmquist TFP indices. Note that the 30 years period after 1980 was divided into 3 decades in order to apply Malmquist TFP indices. The technical efficiency of agricultural sector decreased by $0,3 \%$ in the second period and $0,71 \%$ in the third period compared to the first period. On the other hand, it decreased by $0,68 \%$ in the third period with respect to the second period. In stated periods, scale efficiency is the same with technical efficiency change. Nevertheless, stability of pure efficiency indicates that the change in technical efficiency thoroughly arises from the scale efficiency.

Technical change of the sector decreased by $23.8 \%$ in the second period compared to the first one. However, in 2000's it increased with respect to first and second periods by $3.8 \%$ and $36.2 \%$ respectively. The economic depression of 1990's and the transformation of agricultural support policies in 2000's are the main reason of this change. The result of positive effects of support policies in 2000's is similar with some researches (Coelli and Rao, 2005; Galanopoulos et al., 2004; Armağan et al., 2010).

Table 2. TFP in Turkish agricultural sector

\begin{tabular}{lccccc}
\hline Period & $\begin{array}{c}\text { Efficiency } \\
\text { change }\end{array}$ & $\begin{array}{c}\text { Technical } \\
\text { change }\end{array}$ & $\begin{array}{c}\text { Pure efficiency } \\
\text { change }\end{array}$ & $\begin{array}{c}\text { Scale efficiency } \\
\text { change }\end{array}$ & $\begin{array}{c}\text { TFP } \\
\text { change }\end{array}$ \\
\hline $1980-1989$ & 1 & 1 & 1 & 1 & 1 \\
$1990-1999$ & 0.997 & 0.762 & 1 & 0.997 & 0.759 \\
$2000-2009$ & 0.929 & 1.038 & 1 & 0.929 & 0.964 \\
\hline
\end{tabular}


On the other hand, the results of other researches (Arnade, 1998; Nin et al., 2003; Trueblood and Coggins, 2003; Deliktaş et al., 2005) indicate that the TFP change is negative in Turkey and this change is caused by the technological decline. However, Cankurt et al. (2010) indicates that the reason of negative TFP change is not only the technical efficiency but also technological decline. Finally, TFP in agriculture decreased by $24.1 \%$ in the second period and $3.6 \%$ in the third period when compared to the first one. On the other hand, TFP increased by $27 \%$ in the third period according to the second one. TFP decrease in the second period resulted from both of the two components whereas in the third period, only the technical efficiency is important.

\section{Conclusion}

This paper presents a DEA approach and Malmquist Index to measure TFP and its components in Turkish agriculture from 1980 to 2009. The results show that technically efficient years are considerably observed at the beginning of the first period and in the third period. Furthermore, among the three periods, the average technical efficiency was calculated in the third period. In the second period the reason of TFP decrease is the decline of technological change. On the other hand, in the third period, in spite of the technical efficiency decrease, increase in technological change is the main reason of TFP change. It is most likely a consequence of the support policies implied in the beginning of 2000's. Main feature of the policies in the period is the implementing of market mechanism. It is necessary to improve the competition conditions and to liberate input market for the permanence of market mechanism in agriculture. In this process, the government should have the role of regulation instead of direct intervention to input and product markets. On the other hand, in order to maintain technological development, it is important to support the agricultural sector by $R \& D$ projects and to benefit from support and consultancy services about transferring and adopting new technologies.

\section{References}

Armagan, G., Ozden, A., Bekcioglu, S., 2010. Efficiency and total factor productivity of crop production at NUTS1 level in Turkey: Malmquist index approach. Journal of Quality and Quantity, 44(3):573-581.

Arnade, C., 1998. Using a programming approach to measure international agricultural efficiency and productivity. Journal of Agricultural Economics, 49:67-84.

Avc1, M.A., Kaya, A. A., 2008. The analysis of efficiency and total factor productivity in agricultural sector of Turkey and transition economies (1992-2004). Ege Academic Review, 8(2): 843-860.

Brümmer, B., Glauben, T., Lu, W., 2006. Policy reform and productivity change in Chinese agriculture: A distance function approach. Journal of Development Economics, 81:61-79.
Caves, D.W., Christensen, L.R., Diewert, W. E., 1982. The economic theory of index numbers and the measurement of input, output and productivity. Econometrica, 50(6): 1393-1414.

Cankurt, M., Miran, B., Günden,, C., Şahin, A., 2010. The impacts of global crises on agricultural productivity and efficiency of Turkey and the EU. $9^{\text {th }}$ Turkish Agricultural Economics Congress, 221-228 p., 22-24 September, Şanliurfa.

Chen, P.C., Yu, M.M., Chang, C.C., Hsu, S.H., 2008.Total factor productivity growth in China's agricultural sector. China Economic Review, 19(4): 580-593.

Coelli, T.J., Rao, D.S.P., 2005. Total factor productivity growth in agriculture: a Malmquist index analysis of 93 countries, 1980-2000. Agricultural Economics, 32(1): 115-134.

Deliktaş, E., Ersungur, S.M., Candemir, M., 2005. The comparison of agricultural efficiency and productivity growth in the EU and Turkey. 1980-2002. International Journal of Business Management and Economics, 1: 109-124.

Färe, R., Grosskopf, S., Norris, M., Zhang, Z., 1994. Productivity growth, technical progress, and efficiency change in industrialized countries. American Economic Review, 84: 66-82.

Fulginiti, L.E., Perrin, R.K., 1993. Prices and productivity in agriculture. The Review of Economics and Statistics, 75 (3): 471-482.

Fulginiti, L.E., R.K. Perrin., 1997. LDC agriculture: nonparametric malmquist productivity indexes. Journal of Development Economics, 53: 373-390.

Fulginiti, L.E., Perrin, R.K., 1998. Agricultural productivity in developing countries. Agricultural Economics, 19:45-51.

Galanopoulos, K., Karagiannis, G., Koutroumanidis, T., 2004. Malmquist productivity index estimates for European agriculture in the 1990s. Operational Research, 4(1): 7391.

Kawagoe, T., Hayami, Y., 1985. An intercountry comparison of agricultural production efficiency, American Journal of Agricultural Economics, 67: 87-92.

Kawagoe, T., Hayami, Y., Ruttan, V., 1985. The intercountry agricultural production function and productivity differences among countries. Journal of Development Economics, 19:113-132.

Lau, L., Yotopolous, P., 1989. The meta-production function approach to technological change in the world agriculture. Journal of Development Economics. 31:241269.

Mao, W., Koo, W.W., 1997. Productivity growth, technological progress, and efficiency change in Chinese agriculture after rural economic reforms: a DEA approach. China Economic Review, 8(2):157-174.

Nin, A., Arndt, C., Preckel, P.V., 2003. Is agricultural productivity in developing countries really shrinking? New evidence using a modified nonparametric approach. Journal of Development Economics, 71:395415.

Nkamleu, G.B., 2004. Productivity growth, technical progress and efficiency change in African agriculture. African Development Review, 16(1):203-220.

Thirtle, C., Piesse, J., Lusigi, A., Suhariyanto, K., 2003. Multifactor agricultural productivity, efficiency and convergence in Botswana, 1981-1996. Journal of Development Economics, 71:605-624. 
Trueblood, M.A., Coggins, J., 2003. Intercountry agricultural efficiency and productivity: a malmquist index approach, World Bank, Washington.

Tunca, H., Karaçuka, M., Deliktaş, E., 2014. The competitive power of Turkish agriculture compared to the European Union countries: a dynamic data envelopment analysis. Journal of Economics and Administrative Sciences (Atatürk University), 28(3): 89-105.
Umetsu, C., Lekprichakul, T., Chakravorty, U., 2003. Efficiency and technical change in the Philippine rice sector: A malmquist total factor productivity analysis. American Journal of Agricultural Economics, 85(4):943963.

Zaim, O., Çakmak, E., 1998. Efficiency in Turkish agriculture: trends and comparative analysis. In. Bulutay, T. (Ed), Agricultural Structure and Employment Turkish Statistical Institute, Publication number 2210, 353-378 p. 